\title{
Correction to: Drug-Drug Interactions with Direct Oral Anticoagulants
}

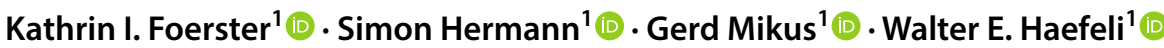

Published online: 30 October 2020

(c) The Author(s) 2020

\section{Correction to: Clinical Pharmacokinetics (2020) 59:967-980 https://doi.org/10.1007/s40262-020-00879-x}

The article Drug-Drug Interactions with Direct Oral Anticoagulants, written by Kathrin I. Foerster · Simon Hermann - Gerd Mikus - Walter E. Haefeli was published under the incorrect Creative Commons (CC) license (CC-BY). The correct license is CC-BY-NC.This article is licensed under a Creative Commons Attribution-Non-commercial 4.0 International License, which permits any non-commercial use, sharing, adaptation, distribution and reproduction in any medium or format, as long as you give appropriate credit to the original author(s) and the source, provide a link to the Creative Commons licence, and indicate if changes were made. The images or other third party material in this article are included in the article's Creative Commons licence, unless indicated otherwise in a credit line to the material. If material is not included in the article's Creative Commons licence and your intended use is not permitted by statutory regulation or exceeds the permitted use, you will need to obtain permission directly from the copyright holder. To view a copy of this licence, visit https://creativecommons .org/licenses/by-nc/4.0/.

The original article has been corrected.

Open Access This article is licensed under a Creative Commons Attribution-NonCommercial 4.0 International License, which permits any non-commercial use, sharing, adaptation, distribution and reproduction in any medium or format, as long as you give appropriate credit to the original author(s) and the source, provide a link to the Creative Commons licence, and indicate if changes were made. The images or other third party material in this article are included in the article's Creative Commons licence, unless indicated otherwise in a credit line to the material. If material is not included in the article's Creative Commons licence and your intended use is not permitted by statutory regulation or exceeds the permitted use, you will need to obtain permission directly from the copyright holder. To view a copy of this licence, visit http://creativecommons.org/licenses/by-nc/4.0/.
The original article can be found online at https://doi.org/10.1007/ s40262-020-00879-x.

\footnotetext{
Gerd Mikus

gerd.mikus@med.uni-heidelberg.de

1 Department of Clinical Pharmacology and Pharmacoepidemiology, Heidelberg University Hospital, Im Neuenheimer Feld 410, 69120 Heidelberg, Germany
} 